\title{
THE ANALYSIS OF NURSE PERFORMANCE DURING COVID-19 PANDEMIC: A CASE STUDY FROM PRIVATE HOSPITAL IN TANGERANG
}

\author{
Retna Yulianti \\ Master's Degree Program in Management, Faculty of Economics and Business, Universitas Esa Unggul \\ Address: J. Arjuna Utara No.9, Duri Kepa, Jakarta Barat, Indonesia 11510 \\ *Email: kfeisha.78@gmail.com
}

\begin{abstract}
The performance of nurses as the front line is crucial in handling covid 19. The purpose of the research was to determine the effect of employee training, employee engagement, and work motivation on nurse performance in the healthcare industry when the COVID-19 pandemic occurred. The object of this research is a nurse with a staff position and a coordinator who works at the AN-NISA hospital located in Tangerang with 140 respondents from February until March 2021. This research uses a quantitative approach which will use questionnaire measuring tools and employee performance data during 2020. Data analysis using path analysis. This research concluded that appropriate employee training, employee engagement, and work motivation had a significant effect on nurse performance. However, employee training and work motivation have no significant effect on nurse performance through employee engagement when the COVID-19 pandemic occurred.
\end{abstract}

Keywords: Employee training, employee engagement, work motivation, nurse performance, COVID-19.

JEL Classification: G3, J5, M12

Article History:

Received: June 22, 2021; Revised: August 11, 2021; Accepted: August 12, 2021; Available Online : August 28, 2021

DOI: $10.20473 /$ imtt.v14i2.27672

\section{INTRODUCTION}

The nurse is one of the leading professions in the COVID-19 era. Liu in The Lancet Global Health said nurses have a role in assessment, meeting daily needs including fluids, nutrition, elimination (defecation/ urination), and personal hygiene. Nurses can minimize complications by carrying out actions starting from screening, emergency, isolation treatment, monitoring hemodynamics and patient condition closely, airway management, changing patient position, providing education to manage critical cases in collaboration with the medical team. (Liv et al., 2020).

The fulfillment of the nurse's duties needs to be supported by the hospital management to maintain the quality and quality of hospital services during the COVID-19 pandemic. Hospital

(c2021 Retna Yulianti. Published in Jurnal Manajemen Teori dan Terapan. Published by Universitas Airlangga, Department of Management. This article is published under the Creative Commons Attribution (CC BY 4.0) licence. 


\section{Retna Yulianti}

quality depends on nurses' performance as the frontline in efforts to control and care in the era of the COVID-19 pandemic. This makes nurses a valuable human resource or employee asset because they can maintain the quality of the hospital when the nurse's performance is good or damage the hospital's reputation when the nurse's performance is terrible and can directly impact profits.

Since the onset of coronavirus disease in November 2019, many studies have been conducted and published to monitor the effects of disease outbreaks on nurses. One of the studies conducted by Nasruloh et al. (2020) stated that $65.8 \%$ of health workers in Indonesia experienced anxiety, 55\% experienced stress, and $23.5 \%$ experienced depression due to the COVID-19 outbreak. However, despite the increasing number of studies on the topic, nothing has been done to examine how the consequences of nurses' motivation and work engagement related to COVID-19 affect the work of nurses as frontline nurses.(Labrague and De los Santos, 2020). COVID-19 can potentially cause long-term effects on nurses' performance and job satisfaction, leading to frequent absenteeism and turnover, resulting in psychological distress, job satisfaction, and intention to leave the organization and the profession. (Labrague and de los Santos, 2021).

Nurses' performance is influenced by various aspects starting from the organizational system in developing potential and opportunities through training programs and attachments to develop and master the field of work to motivational factors in doing their work. (Sendawula et al., 2018). Nurse training programs include assessing and educating patients, providing care, supervising, and coordinating the care process. The main concepts of care training include monitoring vital signs, inserting and removing catheters, changing bandages, basically providing holistic care according to patient needs. If the nurse carries out the training results, the nurse's performance is considered good and can be accounted for. (Nursalam et al., 2020).

The purpose of this study was to find out how the role or influence of training, engagement, and motivation provided by the hospital as an organization on the performance of nurses in the COVID-19 pandemic era. The findings from this study will provide input for policymakers and human resource management in nursing on how to support nurses as the front line and maintain the performance of nurses who are involved effectively, especially during this pandemic. This research is based on the fact that there has been a drastic change in the impact of COVID-19 on training methods, such as online training and not being able to practice in person. 


\section{Jurnal Manajemen Teori dan Terapan \\ Volume 14. No. 2, Agustus 2021}

\section{LITERATURE REVIEW AND HYPOTHESES}

\section{Performance}

Management experts argue that the notion of performance is the work performance of the implementation and goals of the organization carried out by superiors and employees who work in the organization so that organizational goals are achieved. (Nugroho et al., 2020). In Siswoyo (2018), Robbins's view states that actual attitudes at work or performance are formed from several components consisting of evaluation aspects and strong feelings that can guide behavior. (Siswoyo et al., 2018).

The performance can serve as a benchmark for improving health services to maintain the quality of health services provided to healthy and sick patients (Glady et al., 2019). Nurses' performance needs to be evaluated to maintain quality and determine and plan important career development strategies and achieve organizational goals, especially in the era of the COVID-19 pandemic. (Darma Yanti et al., 2020).

Spencer and Spencer define that competence as the characteristics that underlie behavior that describes the motives, personal characteristics (characteristics), self-concept, values, knowledge, or skills brought by a superior performer in the workplace. (Suhartini, 2016). The assessment based on Spencer and Spencer has two dimensions: 1) core competencies and functional competencies.

\section{Employee Training}

Training is an aspect of developing human resource capabilities in every organization. Training is related to improving employee skills and knowledge, which ultimately aims to improve performance. Training is one way to increase individual productivity and quality. (Sendawula et al., 2018).

One of the efforts to deal with the COVID-19 pandemic is comprehensive support by health service providers, namely training programs (Opatha, 2020). The nursing training program requires knowledge and expertise related to handling infectious diseases so that the medical team is sufficiently prepared to handle public health emergencies due to COVID-19(Huang et al., 2020).

Nurbiyati (2017)stated in his research that training evaluation was adopted from the Kirkpatrick Model. Kirkpatrick's evaluation model, known as the Kirkpatrick Four Levels Evaluation Model, 


\section{Retna Yulianti}

developed in 1998, includes four levels of evaluation (level 1 reaction, level 2 learning, level 3 return on investment, and level 4 result). This model reflects Kirkpatrick's opinion that development through training is not something that is expensive and only harms the financial side but is an investment. So that training is an accurate investment calculation of the benefits obtained after carrying out HR development (Nurbiyati, 2017).

\section{Work Engagement}

Work engagement focuses on positive psychology, characterized by how energetic and flexible employees are, how involved they are in their work, and how focused they are in carrying out their duties. (Sendawula et al., 2018).

The increasing workload on nurses in the COVID-19 pandemic reduces nurse engagement in reducing patient suffering related to health during the COVID-19 pandemic on an ongoing basis, which is in line with nurses' ethical obligations to society in a human-centered nursing model (Rosa et al., 2020).

Dimensions of work engagement (work engagement) can be measured with the Utrecht Work Engagement Scale (UWES) to following per under Vigor (spirit), Dedication (dedication), and Absorption (absorbed in work) (Giménez-Espert et al., 2020)

UWES describes a high attachment at work, has a deep focus on the organization, is sensitive to the small important things, is so engrossed in work that he loses time and reduces all kinds of distractions at work. (Kristiana et al., 2019)

\section{Employee Motivation}

Motivation is defined as a psychological process that generates energy within, encourages, and determines behavior in acting in a certain way, initiates, implements, and maintains these activities towards goals. (Nugroho et al., 2020).

Ethical tensions and dilemmas posed by the COVID-19 outbreak and related care provisions impact nurses' work motivation. It is important to evaluate nurses' motivation to work during the COVID-19 pandemic (Rosa et al., 2020). Motivation, according to Herzberg, is influenced by two kinds of need factors: 1) the need for health or the need for maintenance (maintenance factors) and 2) maintenance factors concerning one's psychological needs. (Giménez-Espert et al., 2020). 


\section{Jurnal Manajemen Teori dan Terapan}

Volume 14. No. 2, Agustus 2021

Maintenance factors include physical working conditions, remuneration, supervision, various kinds of allowances and. This need includes a variety of intrinsic conditions and job satisfaction, which will impact a strong level of motivation resulting in a good performance. The motivation Factor includes a series of intrinsic conditions, job satisfaction (job content) which will drive a strong level of motivation when present in the job, which can result in good job performance (Andriani and Widiawati, 2017).

\section{Relationship between Nurse Training and Job Engagement}

Research Allande-Cusso (2021)found a significant difference $(p<0.05)$ between the training and job engagement dimensions. Nurses during the COVID-19 pandemic are a difficult profession because they are at risk of exposure due to lack of knowledge, training in self-protection, and complex service restructuring will impact the mental health of nurses in carrying out their duties. (Allande-Cussó et al., 2021).

Research Labrague (2020) found that there was a significant difference between the level of work engagement $(p<0.05$ ) of nursing training in the COVID-19 pandemic era (Labrague and De Los Santos, 2020). Nurse managers must provide adequate organizational support by implementing a safe work environment, providing complete and quality PPE and equipment to prevent infection, providing accurate and timely information on illness, and implementing training relevant to COVID-19. This organizational practice is very important to support nurses in their nursing practice and improve nurse work engagement in the era of the COVID-19 pandemic(Labrague and De Los Santos, 2020). Based on the statement above, the proposed hypothesis is:

\section{$H_{1}$ : Appropriate nurse training will form high job engagement.}

\section{Relationship between Nurse Motivation and Job Engagement}

The relationship between work engagement and extended working time among nurses; In other words, an excessive service load during the COVID-19 pandemic will affect mental health and decreased work engagement. However, working overtime voluntarily, motivated by personal development and fulfillment, promotes increased work engagement(Gómez-Salgado et al., 2021).

Efforts to ensure a stable work engagement of nurses during the COVID-19 epidemic are to increase the motivation of nurses. The increase in motivation is by recognizing the dedication of nurses as front lines and paying more attention to infection control and physical discomfort 


\section{Retna Yulianti}

caused by PPE. Further interventions should increase confidence in treating patients with infectious diseases (Zhang et al., 2021). Based on the statement above, the proposed hypothesis is:

\section{$\mathrm{H}_{2}$ : High motivation of nurses will form high work engagement.}

\section{Relationship between Nurse Training and Nurse Performance}

Training activities generate benefits or positively impact the performance and growth of individuals, teams, and organizations. Many studies have identified three benefits that employees derive from participating in training, namely personal benefits, career benefits, and work-related benefits. Perceptions of the benefits of training are influenced by previous experience in training which is a key variable for learning in improving employee performance(Sendawula et al., 2018).

A previous study conducted by Elnaga and Imran (2013) stated that training is one of the most important labor-management practices and affects the quality of workers' skills and knowledge, resulting in higher employee performance. The results of employee training are substantial productivity and quality performance (Nugroho et al., 2020).

The COVID-19 outbreak has put tremendous pressure on health services and nurses as the front line facing the impact of COVID-19. In this case, health service providers must focus on psychological support and training for coping strategies to maintain optimal performance and maintain quality. (Huang et al., 2020). Based on the statement above, the proposed hypothesis is:

\section{$\mathrm{H}_{3}$ : Appropriate nurse training will establish high nurse performance.}

\section{Relationship between Nurse Motivation and Nurse Performance}

Work motivation is a competency factor that can change. For example, giving encouragement, appreciation, recognition, and individual attention to employee work can positively affect an employee's motivation so that it will have a positive impact on employee performance(Ma'ruf, 2014). Employee performance is directly affected by intrinsic motivation. Because when employees are intrinsically motivated, they know their performance and work hard to earn rewards(Deressa and Zeru, 2019).

Nurses face various difficulties in their work, especially in the era of the COVID-19 pandemic, for example, work overload, treatment errors, unstable nurse image, decreased work motivation, 


\section{Jurnal Manajemen Teori dan Terapan}

Volume 14. No. 2, Agustus 2021

and work discomfort. The motivational aspect and its factors are an effective way to improve the performance of nurses, especially in the COVID-19 pandemic situation(Yanti et al., 2020). Based on this statement, the proposed hypothesis is:

\section{$\mathrm{H}_{4}$ : High nurse motivation will form high nurse performance.}

Relationship between Nurse Training and Nurse Motivation on Nurse Performance through Job Engagement

Employees exhibit bonded or committed behavior when they dedicate their physical, cognitive, and emotional resources to a work role, by having high energy levels, being enthusiastic about their work, thoroughly enjoying work engagement, leading to high-performing work practices and performance better outcomes at work (Johnson et al., 2018).

Nugroho (2020) argues that committed employees are characterized by motivation, participation, success, enthusiasm, dedication, enthusiasm, and a positive state through positive activities such as improving the quality of human resources that increase employee productivity. (Nugroho et al., 2020).

Employee engagement during the current COVID-19 pandemic is very important in influencing performance and commitment to organizational goals, namely to continue providing quality services. (Radhwan et al., 2020). Based on this statement, the proposed hypothesis is:

\section{$\mathrm{H}_{5}$ : High work engagement will form high nurse performance}

Based on the above hypothetical framework, the research model can be described as follows:

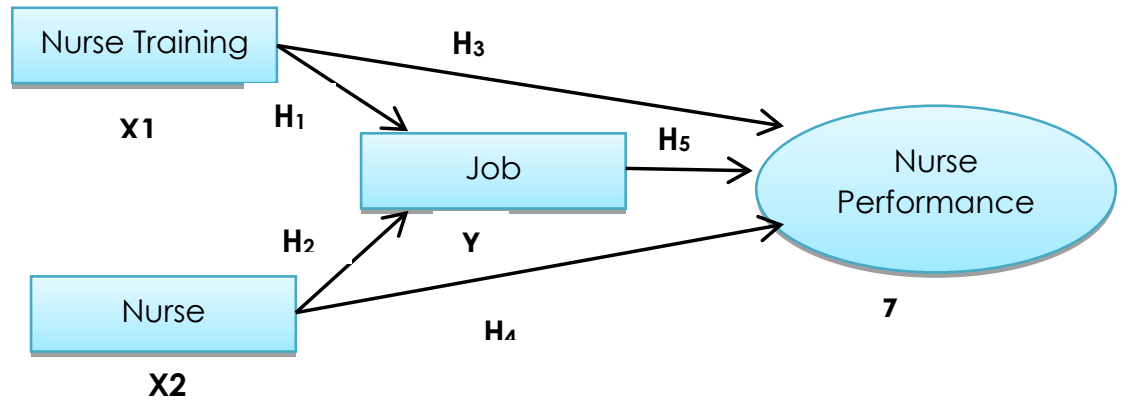

Picture 1.

Influence Model Framework between Employee Training, Work Motivation, Job Engagement, and Nurse Performance Sendawula (2018), Twumasi (2018), Khan (2012), Kasih (2018)) 


\section{Retna Yulianti}

\section{RESEARCH METHODS}

Based on the purpose of this study, the researchers chose the research site at the AN-NISA Hospital Tangerang because the hospital provided the most COVID-19 services in the city of Tangerang with 108 inpatient beds and a special ICU for COVID-19, emergency services for COVID-19 and Sectio Caesarea surgery services in cases of mothers with COVID-19. Compared to other private hospitals, AN - NISA Hospital has the highest COVID-19 bed capacity in Tangerang with 60\%, higher than other private hospitals including Dinda Hospital $26 \%$, Bunda Sejati Hospital 37\%, Pratiwi Hospital $30 \%$, Melati Hospital 34\%, and Sari Asih Hospital $48 \%$

This study uses a quantitative approach with secondary data collection in nurse performance appraisals by direct and primary supervisors from the questionnaire survey method. The research was carried out from February to March 2021 by distributing questionnaires to respondents to fill out the questionnaire through the Google Form.

The sampling technique used in this study is Stratified sampling used to select respondents from each section or installation to ensure that the installation is represented. Simple random sampling was used to select the final respondents in each installation. The selection of respondents in the study was by predetermined inclusion criteria, which consisted of nurses who were employees of the AN-NISA Hospital Tangerang; nurses who did not undergo orientation for six months; nurses who are not on maternity leave; Nurses who are willing to be respondents.

Employee training research variables measured using the employee training evaluation questionnaire developed by Kirkpatrick (1998) and consist of 4 dimensions with eight indicators as follows: reaction dimension consists of two indicators; attitude and influence; learning consists of two indicators, namely knowledge and skills; results consist of two indicators, namely implementation and impact of the relationship; along with cost-effectiveness consists of two indicators, namely efficiency and work effectiveness (Nurbiyati, 2017).

Employee engagement research variables measured using the Utrecht Work Engagement Scale (UWES), which consists of 3 dimensions with ten indicators as follows: Vigor consists of three indicators, namely enthusiasm for work, willingness to try while working, surviving under challenging circumstances; dedication consists of four indicators, namely a sense of responsibility, a sense of pride in work, a feeling of being challenged in work, feeling useful for others); along with absorption consists of three indicators, namely it is difficult to get away from work, pleasure at work, concentration when carrying out tasks (Titien, 2017). 


\section{Jurnal Manajemen Teori dan Terapan \\ Volume 14. No. 2, Agustus 2021}

Work motivation research variables measured by a method taken from Herzberg's theory, consisting of 2 dimensions with ten indicators with the following Hygiene Factor/Maintenance Factors consisting of five indicators namely salary, working conditions, company policies, and administration, interpersonal relationships, and quality of supervision; and Motivation factors consist of five indicators, namely achievement, recognition, work, responsibility and individual potential development(Andriani and Widiawati, 2017). The measuring scale in this research instrument uses a Likert scale, with four alternative answers are: strongly disagree (STS); disagree (TS); agree (S), strongly agree (SS).

Meanwhile, the nurse's performance research variable was measured by secondary data through a performance evaluation process arranged in the AN-NISA Hospital Performance Assessment Guide Tangerang. Performance appraisal adopted from Spencer and Spencer has two dimensions: 1) core competence and functional competence. The nurse performance category is divided into four categories: unsatisfactory with a score of $<69$, quite good with a score of 70-79, good with a score of 80-95, and extraordinary with a score of 96-100.

Before being applied to the actual research, the research instrument will be tested first. The trial was carried out to ensure that the instrument compiled was good because it would affect whether the data was correct or not. The value of validity and reliability describes the good or bad of the instrument to know its feasibility in research on nurses who work at the AN-NISA Hospital Tangerang. This instrument was tested on 30 respondents who were not included in the population of the actual research sample. The instrument test results of 40 questions, which were declared valid and reliable, were 35 questions with Cronbach's Alpha value of 0.747.

Researchers will use samples based on calculations from the population of nurses working at the AN-NISA Hospital Tangerang, which consists of 220 nurses using the Krejcie and Morgan tables in 1970. The respondents used in this study were 140 nurses. The testing phase carried out from this research is the linear test regression involving more than one variable assisted by a statistical computer program.

The regression model is feasible if the significance number on ANOVA of $<0.05$. The predictor used as the independent variable must be feasible. This feasibility is known if the Standard Error of Estimate < Standard Deviation. The regression coefficient must be significant. The test is carried out with a T-test. The regression coefficient is significant if T count $>$ T table (critical value). 


\section{Retna Yulianti}

\section{RESULTS AND DISCUSSION}

The results of the research from 140 nurse respondents who worked at the AN-NISA Hospital Tangerang showed that the majority of respondents were women by $83.6 \%$, aged between 21 30 years by $85.7 \%$, with the last education of Bachelor (S1) at $100 \%$, staff/executive nurses. By $93.6 \%$, length of service from $1-5$ years by $76.4 \%$. This shows that nurses who work at the AN-NISA Hospital are young people with a fairly high education Bachelor (S1) with a position as an implementing nurse who starts their work from 1 to 5 years at AN-NISA Hospital Tangerang.

Table 1.

Research Hypothesis Test Results

\begin{tabular}{|c|c|c|c|c|c|c|}
\hline Path Analysis & $\begin{array}{l}\text { Independent } \\
\text { Variable }\end{array}$ & $\begin{array}{l}\text { Dependent } \\
\text { variable }\end{array}$ & $\begin{array}{c}\text { P- } \\
\text { Value }\end{array}$ & $\begin{array}{c}\mathbf{R} \\
\text { Square }\end{array}$ & e value & Beta $(\beta)$ \\
\hline \multirow[t]{2}{*}{$\begin{array}{l}\text { Model Path } \\
\text { Coefficient } 1\end{array}$} & $\begin{array}{l}\mathrm{X} 1 \text { (Nurse } \\
\text { training) }\end{array}$ & \multirow{2}{*}{$\begin{array}{c}\mathrm{Y} \\
\text { (Employment } \\
\text { Engagement) }\end{array}$} & 0.000 & \multirow[t]{2}{*}{0.653} & \multirow[t]{2}{*}{$\begin{aligned} \text { e1: } & (1-0.653) \\
& =0.589\end{aligned}$} & 0.640 \\
\hline & $\begin{array}{c}\text { X2 (Nurse } \\
\text { Motivation) }\end{array}$ & & 0.000 & & & 0.278 \\
\hline \multirow[t]{3}{*}{$\begin{array}{l}\text { Model Path } \\
\text { Coefficient } 2\end{array}$} & $\begin{array}{l}\text { X1 (Nurse } \\
\text { training) }\end{array}$ & \multirow[t]{3}{*}{$\begin{array}{c}\text { Z (Nurse } \\
\text { Performance) }\end{array}$} & 0.085 & \multirow[t]{3}{*}{0.147} & \multirow[t]{3}{*}{$\begin{array}{l}\text { e2: }(1-0.147) \\
\quad=0.923\end{array}$} & 0.215 \\
\hline & $\begin{array}{c}\text { X2 (Nurse } \\
\text { Motivation) }\end{array}$ & & 0.040 & & & 0.201 \\
\hline & $\begin{array}{l}\text { Y (Employment } \\
\text { Engagement) }\end{array}$ & & 0.802 & & & 0.034 \\
\hline \multicolumn{7}{|c|}{ Intervening Variable Analysis } \\
\hline Hypothesis & Direct Influence & $\begin{array}{l}\text { Indirect } \\
\text { Influence }\end{array}$ & \multicolumn{2}{|c|}{ Total Influence } & \multicolumn{2}{|c|}{ Information } \\
\hline $\begin{array}{c}\text { Effect of } X 1 \\
\text { through } Y \text { on } Z\end{array}$ & 0.215 & $\begin{array}{c}0.640 \times 0.034= \\
0.02176\end{array}$ & \multicolumn{2}{|c|}{$\begin{array}{c}0.215+0.02176= \\
0.2367\end{array}$} & \multicolumn{2}{|c|}{$\begin{array}{l}\text { Indirectly X1 through } \\
\text { Y does not have a } \\
\text { significant effect }\end{array}$} \\
\hline $\begin{array}{c}\text { Effect of X2 } \\
\text { through } Y \text { on } Z\end{array}$ & 0.201 & $\begin{array}{c}0.278 \times 0.034= \\
0.00945\end{array}$ & \multicolumn{2}{|c|}{$\begin{array}{c}0.201+0.00945= \\
0.21045\end{array}$} & \multicolumn{2}{|c|}{$\begin{array}{l}\text { Indirectly X2 through } \\
\text { Y does not have a } \\
\text { significant effect }\end{array}$} \\
\hline
\end{tabular}

Source: Processed data of linear regression statistical test using SPSS (2020) 


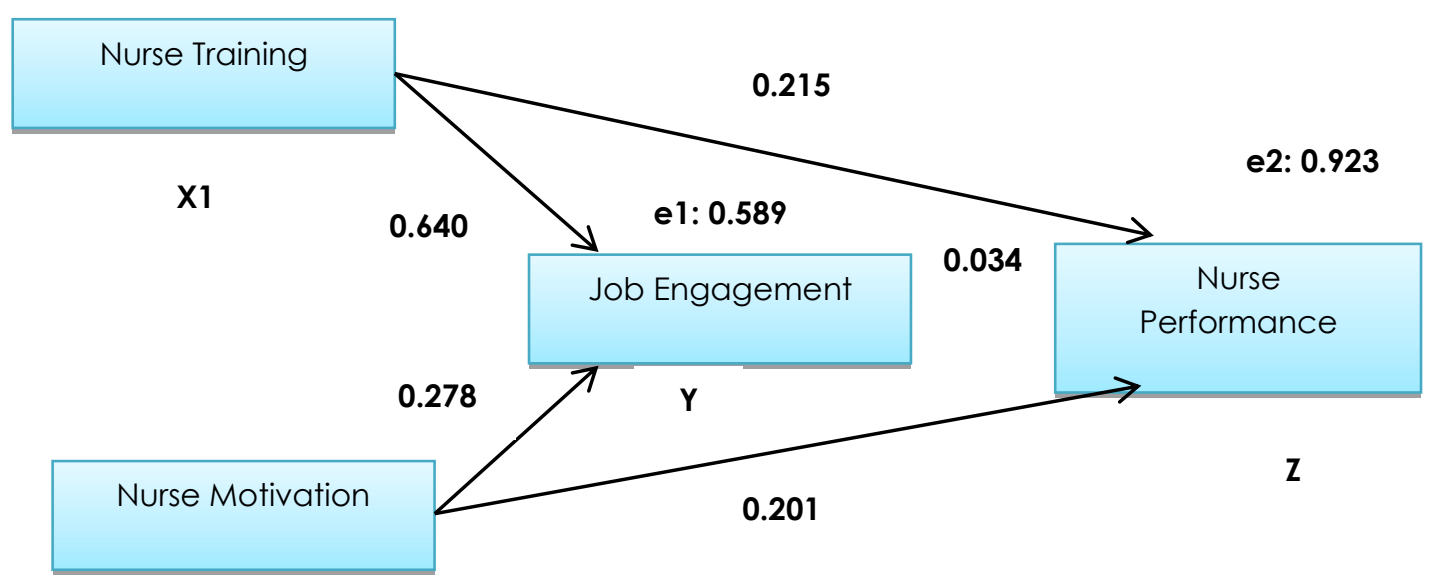

Picture 2.

Model Framework for Hypothesis Test Results Effects between Employee Training, Work Motivation, Job Engagement, and Nurse Performance

$\mathrm{H}_{1}$ : the appropriate nurse training variable affects high work engagement in the COVID19 pandemic era

$\mathrm{H}_{2}$ : $\quad$ high nurse motivation affects work engagement

$\mathrm{H}_{3}$ : training affects nurse performance

$\mathrm{H}_{4}$ : the positive effect of high motivation on the performance of nurses in the era of the COVID-19 pandemic

$\mathrm{H}_{5}$ : training and motivation of nurses have no significant effect through work engagement on nurse performance

The variables of nurse training and motivation of nurses affect $65.3 \%$ of work engagement, while $34.7 \%$ are influenced by other variables not examined. Hypothesis test value $p$-value $<0.05$ (0.000), then the hypothesis has a significant effect.

The variables of nurse training, nurse motivation, and work engagement affect $14.7 \%$ of nurse performance, while $85.3 \%$ are influenced by other variables not examined. The value of the $\mathrm{p}$ value hypothesis test between nurse training and work engagement on nurse performance is $>$ 0.05 (0.085 and 0.802), then the hypothesis has no significant effect. While the value of the hypothesis test $\mathrm{p}$-value between the motivation of nurses on the performance of nurses $<0.05$ (0.040), then the hypothesis has a significant effect. 


\section{Retna Yulianti}

Intervening variable analysis of nurses' training and motivation on nurse performance through work engagement did not have a significant relationship or effect because the direct effect was greater than the indirect effect $(0.215>0.02176$ and $0.201>0.00945)$.

\section{Discussion}

Our results agree with findings from prior studies, especially Allande-Cussó (2021) and Larague (2020) stated that nursing during the COVID-19 pandemic was a difficult profession due to lack of knowledge, training in self-protection, and complex service restructuring, so that has an impact on work engagement and function as a nurse. Darma Yanti's research (2020) states that the factors that influence the motivation of nurses in the COVID-19 pandemic are the risk of transmission at work, the application of prevention procedures, and compensation or guarantees that nurses will get, and the results of research. The results obtained are under those studied, but the motivation is carried out at the research site by providing a spiritual approach and reminding nurses to maintain health protocols even at home because nurses worry about transmitting the family.

This research intends to exploit the influence between variables of nurse training, work engagement, and work motivation on the performance of nurses in the era of the COVID-19 pandemic. The study results found that the appropriate nurse training variable affected high work engagement in the COVID-19 $\left(\mathrm{H}_{1}\right)$ pandemic era. The results of this study are in line with the research proposed by Allande-Cusso (2021) and Labrague (2020), which stated that nurses during the COVID-19 pandemic were a difficult profession due to lack of knowledge, training in self-protection, and complex service restructuring that had an impact on work engagement and functions as nurses. (Allande-Cussó et al., 2021).

Training and development can provide competent quality for nurses to adapt to the changing conditions due to the COVID-19 pandemic. Improving the quality of nurse competence will provide the best service for people with COVID-19, which naturally increases job satisfaction and nurses' engagement with their duties and functions. (Azmy, 2019).

The study results found that the motivation of nurses has a high effect on work engagement $\left(\mathrm{H}_{2}\right)$. The results of this study are in line with the research of Gómez-Salgado (2021) because the excessive service burden during the COVID-19 pandemic will affect the motivational factor according to Herzberg's theory which has an impact on work absenteeism. (Gómez-Salgado et al., 2021). 


\section{Jurnal Manajemen Teori dan Terapan \\ Volume 14. No. 2, Agustus 2021}

Work engagement is an important factor that nurses must maintain in the COVID-19 pandemic era because of awareness of the importance of the work that must be done. Many studies have identified that nurses can maintain work engagement with values of caring, attitude (optimism), shared beliefs (religion), professional skills in the context of the work environment, and available support). This fact can direct nurses who cultivate an element of motivation to the special impact of COVID-19 in their work(Giménez-Espert et al., 2020).

In this test, it has been stated that training does not affect the performance of nurses $\left(\mathrm{H}_{3}\right)$. This states that appropriate training does not make nurses have high performance in the era of the COVID-19 pandemic. The results of this study are in line with the findings of Sperling (2021)that no significant correlation was found between education level, nurses' attitudes towards work, and training about the health system during the COVID-19 pandemic on nurses' performance. This fact is influenced by two factors: experience and perception of risk of exposure to COVID-19. More experienced nurses were happier with their decision to work in the health system during the COVID-19 pandemic than less experienced nurses. In addition, the higher the nurse's perception of personal risk, the more unhappy they are about their decision to work in the current health system. The more worried they will be about the impact of the pandemic on their career so that the nurse's performance will be less than optimal.

This study has proven that there is a positive influence of high motivation on the performance of nurses in the era of the COVID-19 pandemic $\left(\mathrm{H}_{4}\right)$. This result is because the motivation felt by respondents during the COVID-19 pandemic was the most important psychological factor at work in the form of personal rewards when work targets were achieved and basic needs that were needed continuously to support the quality of life and work.

These results are by the research of Darma Yanti (2020), which states that Factors that affect the motivation of nurses in the era of the COVID-19 pandemic are the risk of transmission in the workplace, the implementation of prevention procedures, and the compensation or guarantees that nurses will get (Yanti et al., 2020). This statement is also in line with the majority of studies on job satisfaction based on the motivational theory of Herzberg and Mausner about the factors that lead to dissatisfaction and remain significant in the era of the COVID-19 pandemic. (Leskovic et al., 2020).

This statement is by research on the application of Herzberg's theory to increase the motivation of nurses in the era of the COVID-19 pandemic is a guarantee and organizational commitment that there is no shortage of personal protective equipment (PPE). The physical burden caused 


\section{Retna Yulianti}

by wearing it and the fear of being infected can endanger family members. The conflict between safety procedures and desire to provide support, longer working hours, suppress multitasking, and stigmatization of people working in high-risk environments (Giorgi et al., 2020).

On the other hand, the training and motivation of nurses do not have a significant effect through work engagement on nurse performance $\left(\mathrm{H}_{5}\right)$. This is because attachment, according to nurses, is only limited to morale, a work atmosphere, the desire to try while working, feeling able to give the best at work, surviving in difficult circumstances, and being able to adapt when difficult situations at work (Panisoara et al., 2020). At the same time, a nurse who works in a hospital in the pandemic era can improve her performance results by feeling proud of her work, feeling challenged, feeling happy when she is given a job that has challenges, feeling useful for others, feeling able to help colleagues, difficult to get away from work when you are working, you are often carried away by the work atmosphere, a sense of pleasure at work when working continuously, concentration and focus when carrying out tasks (Radhwan et al., 2020).

This statement is in line with research conducted by Giménez-Espert et al. (2020), which states that the impact of the COVID-19 pandemic on nurses is not only psychosocial risk and nurses' perceptions but also aspects of job satisfaction that have a positive effect on nurse performance. During this COVID-19 pandemic, motivation through emotional enhancement, training, information, and good communication will impact performance achievement(Radhwan et al., 2020). The implications for the policymaker in the healthcare industry are to review the performance assessment of supporting nurses during the COVID-19 pandemic on a standard basis. So, it can be carried out objectively, increase knowledge about nurse training conducted online or provide training videos that can increase nurse's knowledge about how to handle COVID-19 patients. To keep nurses engaged and motivated with scholarships and career paths.

\section{CONCLUSION}

Based on the results of this study, it is concluded that the motivation of nurses has a significant influence on the nurse's performance in the COVID-19 pandemic and has a crucial role in improving the performance of nurses in the COVID-19 pandemic.

The implications of this research are expected to be useful for hospitals in dealing with the COVID-19 pandemic, which can be used as an illustration that hospitals need to provide adequate organizational support through the implementation of a safe work environment, 


\section{Jurnal Manajemen Teori dan Terapan \\ Volume 14. No. 2, Agustus 2021}

providing complete quality PPE and equipment to prevent infection, providing accurate and timely information regarding the disease and the implementation of training relevant to COVID19. This organizational practice is very important to support nurses in their nursing practice, increase motivation, and produce optimal nurse performance in the COVID-19 pandemic (Labrague and De Los Santos, 2020). The implications for policymakers in the health care industry are to improve the performance of nurses on duty in the COVID-19 room by providing rewards, conducting regular screening, and providing protection for nurses by providing personal protective equipment by following the standards recommended by WHO.

One of the efforts to ensure stable work engagement and performance of nurses during the COVID-19 pandemic is by increasing the motivation of nurses. The increase in motivation is by recognizing the dedication of nurses as front lines and paying more attention to infection control and physical discomfort caused by PPE. Further interventions should increase confidence, knowledge, and skills in caring for patients with infectious diseases (Zhang et al., 2021).

The implications of the research for researchers can be used as basic data to research with qualitative or mixed methods to find out the factors that most influence the performance of nurses, given that nurses are important human resources in dealing with the COVID-19 pandemic. The purpose of developing human resources by knowing the most influential factors is to improve the quality of professionalism and skills of nurses from carrying out their duties and functions as nurses so that they can further improve the performance of nurses.

The limitations of this study can be considered for further research. This study uses a questionnaire as a research instrument to save time and effort. However, this questionnaire has limitations in filling out questions. There is a possibility that the respondent did not answer the questionnaire in real or just answered filling out the answers to the questionnaire based on the expected ideal conditions and not the actual conditions that occurred. In addition, there are limitations in distributing questionnaires and performance assessments according to the guidelines that only apply and are carried out at the AN-NISA Hospital. Therefore, future research could examine the larger respondents or larger scope.

Further research can be carried out in all lines in one area at a specific time by involving nurses involved in COVID-19 care to improve the accuracy of data analysis. Add research variables such as psychological well being, job satisfaction, burnout, and so on so that the results of data and variables are more varied to be studied. The results of this study state that organizations 


\section{Retna Yulianti}

cannot ignore appropriate and regular training needed by employees even in the COVID-19 pandemic era to maintain work engagement and motivation so that employee performance remains optimal.

\section{REFERENCES}

Allande-Cussó, R., García-Iglesias, JJ, Ruiz-Frutos, C., Domínguez-Salas, S., Rodríguez-Domínguez, C., and Gómez-Salgado, J. 2021. Work engagement in nurses during the covid-19 pandemic: A cross-sectional study. Healthcare (Switzerland), 9(3): 1-11. https://doi.org/10.3390/healthcare9030253

Andriani, M., and Widiawati, K. 2017. Application of Employee Motivation According to Frederick Herzberg's Two-Factor Theory at PT Aristika Kreasi Mandiri. 5(1): 83-98.

Azmy, A. 2019. Nurse Engagement Factors in the COVID-19 Pandemic. Nurse Media Journal of Nursing, 10(3): 187-200. https://doi.org/10.21512/bbr.v10i3.5857

Darma Yanti, NPE, Susiladewi, IAMV, and Pradiksa, H. 2020. An overview of the motivation to work as a nurse during the Coronavirus Disease (Covid-19) Pandemic in Bali. Coping: $\begin{array}{llll}\text { Community of Publishing } & 55 .\end{array}$ https://doi.org/10.24843/coping.2020.v08.i02.p07

Deressa, AT, and Zeru, G. 2019. Work motivation and its effects on organizational performance: The case of nurses in Hawassa public and private hospitals: Mixed method study approach. BMC Research Notes, 12(1): 1-7. https://doi.org/10.1186/s13104-019-4255-7

Espino-Díaz, L., Fernandez-Caminero, G., Hernandez-Lloret, CM, Gonzalez-Gonzalez, H., and Alvarez-Castillo, JL. 2020. Analyzing the impact of COVID-19 on education professionals. Toward a paradigm shift: ICT and neuroeducation as a binomial of action. Sustainability (Switzerland), 12(14): 1-10. https://doi.org/10.3390/su12145646

Giménez-Espert, M. del C., Prado-Gascó, V., and Soto-Rubio, A. 2020. Psychosocial Risks, Work Engagement, and Job Satisfaction of Nurses During the COVID-19 Pandemic. Frontiers in Public Health, 8(November): 1-10. https://doi.org/10.3389/fpubh.2020.566896

Giorgi, G., Lecca, LI, Alessio, F., Finstad, GL, Bondanini, G., Lulli, LG, Arcangeli, G., and Mucci, N. 2020. COVID-19-related mental health effects in the workplace: A narrative review. International Journal of Environmental Research and Public Health, 17(21): 1-22. https://doi.org/10.3390/ijerph17217857

Gómez-Salgado, J., Domínguez-Salas, S., Romero-Martín, M., Romero, A., Coronado-Vázquez, V., 


\section{Jurnal Manajemen Teori dan Terapan \\ Volume 14. No. 2, Agustus 2021}

and Ruiz-Frutos, C. 2021. Work engagement and psychological distress of health professionals during the COVID-19 pandemic. Journal of Nursing Management, December 2020: 1-10. https://doi.org/10.1111/jonm.13239

Huang, L., Lei, W., XU, F., Liu, H., and YU, L. 2020. Emotional responses and coping strategies in nurses and nursing students during the Covid-19 outbreak: A comparative study. PLoS ONE, 15(8 August): 1-12. https://doi.org/10.1371/journal.pone.0237303

Inap, R., Liun, R., Tahuna, K., and Sangihe, K. 2019. Relationship between work motivation and nurse performance at the inpatient unit of the Liun Kendage Tahuna Hospital, Sangihe Regency. Public Health, 7(5).

Johnson, KR, Park, S., and Bartlett, KR. 2018. Perceptions of customer service orientation, training, and employee engagement in Jamaica's hospitality sector. European Journal of Training and Development, 42(3-4): 191-209. https://doi.org/10.1108/EJTD-11-2017-0094

Kristiana, IF, Fajrianthi, F., and Purwono, U. 2019. Rasch analysis in the Indonesian version of the Utrecht Work Engagement Scale-9 (Uwes-9). Journal of Psychology, 17(2): 204. https://doi.org/10.14710/jp.17.2.204-217

Larague, LJ, and de los Santos, JAA. 2021. Fear of COVID-19, psychological distress, work satisfaction, and turnover intention among frontline nurses. Journal of Nursing Management, 29(3): 395-403. https://doi.org/10.1111/jonm.13168

Larague, LJ, and De los Santos, JAA. 2020. COVID-19 anxiety among frontline nurses: Predictive role of organizational support, personal resilience and social support. Journal of Nursing Management, 28(7): 1653-1661. https://doi.org/10.1111/jonm.13121

Leskovic, L., Erjavec, K., Leskovar, R., and Vukovič, G. 2020. Burnout and job satisfaction of healthcare workers in Slovenian nursing homes in rural areas during the covid-19 pandemic. Annals of Agricultural and Environmental Medicine, 27(4): 664-671. https://doi.org/10.26444/aaem/128236

Liu, Q., Luo, D., Haase, JE, Guo, Q., Wang, XQ, Liu, S., Xia, L., Liu, Z., Yang, J., and Yang, BX. 2020. The experiences of healthcare providers during the COVID-19 crisis in China: a qualitative study. The Lancet Global Health, 8(6): e790-e798. https://doi.org/10.1016/S2214$109 \times(20) 30204-7$

Nugroho, Marno and Paradifa, R., and Renjana. 2020. Effect of Training, Motivation, Competence on Human Resource Performance. Indonesian Journal of Science 


\section{Retna Yulianti}

$\begin{array}{llll}\text { Management } \quad \text { Research } & \text { (JRMSI), }\end{array}$ http://journal.unj.ac.id/unj/index.php/jrmsi/issue/view/1 102

Nurbiyati, T. 2017. Human Resource Development Evaluation: A Review. STIE Widya Wiwaha Business Studies, 23(1): 52-63. https://doi.org/10.32477/jkb.v23i1.203

Nursalam, N., Sukartini, T., Maf'ula, D., and Priyantini, D. 2020. Quality of Nursing Worklife Based on Caring Model for Improving Nurse Performance in Hospitals. Indonesian Nursing Journal of Education and Clinic (Inject), 5(2): 172. https://doi.org/10.24990/injec.v5i2.339

Opatha, HHDNP. 2020. The Coronavirus and The Employees: A Study from the Point of Human Resource Management. Sri Lankan Journal of Human Resource Management, 10(1): 37. https://doi.org/10.4038/sljhrm.v10il.5649

Panisoara, 1O, Lazar, I., Panisoara, G., Chirca, R., and Ursu, USA. 2020. Motivation and continuance intention towards online instruction among teachers during the COVID-19 pandemic: The mediating effect of burnout and technostress. International Journal of Environmental Research and Public Health, 17(21): 1-29. https://doi.org/10.3390/ijerph17218002

Prof. Dr. HM Abdullah Ma'ruf, SM. 2014. Employee Performance Management and Evaluation. In the National Library of Indonesia.

Radhwan, M., Alzgool, H., Ahmed, U., and Hussain, M. 2020. COVID-19 and Work Engagement: Understanding the Nexus of Leaders Emotional Intelligence Self-efficacy and Resilience in the Banking Sector of Bahrain. Revista Argentina de Clínica Psicológica, XXIX: 568-586. https://doi.org/10.24205/03276716.2020.760

Rosa, WE, Ferrell, BR, and Wiencek, C. 2020. Increasing critical care nurse engagement of palliative care during the covid-19 pandemic. Critical Care Nurse, 40(6): e28-e36. https://doi.org/10.4037/ccn2020946

Sendawula, K., Nakyejwe Kimuli, S., Bananuka, J., and Najjemba Muganga, G. 2018. Training, employee engagement and employee performance: Evidence from Uganda's health sector. Cogent Business and Management, 5(1): 1-12. https://doi.org/10.1080/2331 1975.2018.1470891

Sperling, D. 2021. Ethical dilemmas, perceived risk, and motivation among nurses during the COVID-19 pandemic. Nursing Ethics, 28(1): 9-22. https://doi.org/10.1177/0969733020956376

Suhartini, E. 2016. The influence of competence on employee performance (comparative study 


\section{Jurnal Manajemen Teori dan Terapan}

Volume 14. No. 2, Agustus 2021

between the Faculty of Economics and Islamic Business and the Faculty of Sharia and Law of Uinam). Journal of UIN Alauddin Faculty of Economics and Islamic Business, Vol. 3(No. 5): 61-78.

Titien, T. 2017. Preparation and Development of Employee Engagement Measurement Tools. Psychohumanities: Journal of Psychological Research, 1(1): 113. https://doi.org/10.21580/pjpp.v1i1.958

Zhang, M., Zhang, P., Liu, Y., Wang, H., Hu, K., and Du, M. 2021. Influence of perceived stress and workload on work engagement in frontline nurses during the COVID-19 pandemic. Journal of Clinical Nursing, December 2020: 1584-1595. https://doi.org/10.1111/jocn.15707 